\section{1. わが国における頭部外傷データバンクの試み}

東京慈恵会医科大学脳神経外科・救急部* 小川武希*, 頭部外傷データバンク検討委員会， 日本神経外傷学会

頭部外傷データバンク検討委員会は重傷頭部外傷患者の臨 床疫学的検討を目的とし, 救命救急センターをもつ全国の脳 神経外科 10 施設長, 実行委員で構成される。共通のデー夕 シートを改訂，作成し，この医学的基礎資料の結果から行政， 工学系との連携において, 頭部外傷の予防, 治療, 予後研究 を目的とする，1998〜2000年まで 3 年間のデー夕の集積が行 われた，対象症例は 6 歳以上の症例。来院時あるいは経過中 にGCS 8 以下となった 712 症例が調查分析対象となった。わ が国に抬ける重症頭部外傷の病院搬送前治療状況, 初期診断, 初期治療などの実態の全体像が示された。また，わが国の臨 床統計に対する行政の関与のあり方，頭部外傷の分類自体の 困難性，予後調査などいくつかの基本的な問題点が明らかに なった，データバンクは現在も進行中であるが，現時点での 中間報告の概説を行う。

\section{2. 重症頭部外傷の治療成績}

京都九条病院脳神経外科, 済生会滋賀県病院脳神経外科*, 日本大学文理学部数学教室 $* *$ 山木 垂水, 藤本 正人*, 森 真 ${ }^{*}$, 頭部外傷データバンク検討委員会, 日本神経外傷学会

重症頭部外傷の治療は，その病態が画像診断学や生理学的 検索方法の進歩により明らかにされていくとともに，いくつ かの治療法が試行され改善されつつある。 そんななか, 日本 神経外傷学会は，1998２000年に，全国10施設に収容され たGCS 8 以下の症例 712 例を集計し，「頭部外傷データバン ク」を作成し，多方面からの分析を行った．今回の発表はそ のなかから，「重症頭部外傷の治療」という観点から分析し た結果を発表する。

すなわち，現在わが国では，いかなる脳の外傷性損傷に対 し，どのような治療がなされており，その結果がいかなるも のであったかを，特に手術例，非手術例の治療成績の比較と いう観点から分析した。またそれぞれの病態に対する手術方 法や治療方針に, 各施設間の差があることが考元られるため, この件に関しても分析を加えた。

\section{3. 外傷性脳動脈損傷の法医学}

福島県立医科大学法医学, 同脳神経外科学* 平岩 幸一, 郡司 啓文, 水澤 郁文, 佐藤 拓*, 児玉南海雄*

過去 17 年間の法医解剖例から, 歩行者等と車両との衝突 による延髄・頸髄損傷例につき, 脳血管損傷部位を解析した。 その結果，頸髄損傷群では脳底部動脈に損傷は見当たらず, 延髄損傷群に脳底動脈領域の血管断裂・離断が認められた。 一方，交通事故ほどの激しい外力でなくても，頭頸部への打 撲直後の死亡例では，椎骨動脈損傷によるクモ膜下出血（単 独性外傷性クモ膜下出血；ITSAH）が稀ならずみられた。 17 年間における頭部の軪過以外の致死的頭部外傷例に占め るITSAH の割合は $10.7 \%$ で，即死例の多くは椎骨動脈が血 管走行に沿って破裂，すなわち，縦方向の亀裂を認めた，頸 部過進展という旁引力では脳底部動脈離断となるが，頭部へ の回転力では椎骨動脈が縦裂する。縦裂部に相当する椎骨動 脈は，正常者でも内弾性板の欠損頻度が高く，同部の脆弱性 を示唆する。

\section{4. 交通外傷と高次脳機能障害}

新東京病院脳神経外科, 同総合診療科 ${ }^{1)}$, 武蔵野赤十字病院脳神経外科 ${ }^{2)}$, 東京慈恵会医科大学 33

益澤 秀明, 平川 公義1),

富田 博樹2)，中村 紀夫 ${ }^{3)}$

交通事故ではびまん性軸索損傷などの脳外傷が起こりやす いことが知られている。脳外傷後には特徵的な認知障害，人 格変化，社会生活適応障害が急性期に発生し，かつ後遺症と して残りやすい。しかしながら，こうした障害は専門家に よっても日常診察では見過ごされやすいため，わが国の社会 問題にもなり，いつとはなしに“高次脳機能障害”とよばれ るようになった。このため, 従来から知られている高次脳 （皮質）機能障害と紛らわしくなり，混乱が生じている.

ここでは，交通事故被害者の高次脳機能障害審査基準を基 に, 脳外傷による高次脳機能障害の特徵的な臨床像, 検查所 見，診断と重症度評価の拠り所，見過ごさないためのヒント， 紛らわしい疾患との鑑別などについて解説する。なかでも， 決め手となる脳画像検查に扔いて特徵的な所見がありながら 従来見逃されてきたポイントを示す，急性期管理に携わる脸 神経外科医の眼が，後遺症評优においても重要である. 